\title{
Treatment of Cutaneous Ulcers with Multilayered Mixed Sheets of Autologous Fibroblasts and Peripheral Blood Mononuclear Cells
}

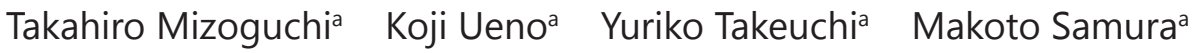 \\ Ryo Suzuki $^{\mathrm{a}}$ Tomoaki Murata ${ }^{\mathrm{b}}$ Tohru Hosoyama ${ }^{c}$ Noriyasu Morikage \\ Kimikazu Hamano ${ }^{a}$
}

aDepartments of Surgery and Clinical Sciences, Graduate School of Medicine, Yamaguchi University, Ube, Yamaguchi, 'Institute of Laboratory Animals, Yamaguchi University, Ube, Yamaguchi, 'Department of Regenerative Medicine, Research Institute, National Centre for Geriatrics and Gerontology, Aichi, Japan

\section{Key Words}

Cell sheets $•$ Fibroblasts $•$ Peripheral blood mononuclear cells $\bullet$ Skin ulcers $•$ Angiogenesis

\begin{abstract}
Background/Aims: We have developed a mixed-cell sheet consisting of autologous fibroblasts and peripheral blood mononuclear cells with a high potency for angiogenesis and wound healing against refractory cutaneous ulcers in mouse and rabbit models. To increase the effectiveness of the mixed sheet, we developed a multilayered mixed sheet. Methods: We assessed the therapeutic effects of multilayered sheets on cutaneous ulcers in mice. Growth factors and chemokines were assessed by enzyme-linked immunosorbent assay. Angiogenesis and fibroblast migration were measured by using tube formation and migration assays. Wound healing rate of cutaneous ulcers was evaluated in mice with diabetes mellitus. Results: The concentration of secreted vascular endothelial growth factor, hepatocyte growth factor, transforming growth factor, $\mathrm{C}-\mathrm{X}-\mathrm{C}$ motif chemokine ligand $(\mathrm{CXCL})-1$, and $\mathrm{CXCL}-2$ in multilayered sheets was much higher than that in single-layered mixed-cell sheets (singlelayered sheets) and multilayered sheets of fibroblasts alone (fibroblast sheets). The supernatant in multilayered sheets enhanced angiogenic potency and fibroblast migration compared with single-layered and fibroblast sheets in an in vitro experiment. The wound healing rate in the multilayered sheet-treated group was higher compared with the no-treatment group (control) at the early stage of healing. Moreover, both vessel lumen area and microvessel density in tissues treated with multilayered sheets were significantly increased compared with tissues in the control group. Conclusion: Multilayered sheets promoted wound healing and microvascular angiogenesis in the skin by supplying growth factors and cytokines. Accordingly, our data suggest that multilayered sheets may be a promising therapeutic material for refractory cutaneous ulcers.




\section{Cellular Physiology Cell Physiol Biochem 2018;47:201-211 and Biochemistry Published online: May 16, $2018 \quad$\begin{tabular}{l|l} 
DOI: 10.1159/000489767 2018 The Author(s). Published by S. Karger AG, Basel \\
www.karger.com/cpb
\end{tabular} Ueno et al.: Treatment of Cutaneous Ulcers with Multilayered Mixed Sheets}

\section{Introduction}

Refractory skin ulcers are caused by ischemic disorders including peripheral arterial disease (PAD), diabetes mellitus, and pressure and congestive disorders (e.g. venous insufficiency), and therapies are tailored according to the cause [1-4]. More than 200 million people are affected by PADs globally, including arteriosclerosis obliterans, Buerger's disease, and blue toe syndrome [5]. Although revascularisation via endovascular and bypass surgery methods is the best treatment for critical limb ischemia (CLI), complications can be encountered and some patients are not suitable candidates for revascularization [6]. Even if surgical treatment is successful, if a local circulatory disorder remains, the cutaneous ulcer might be refractory. Therapeutic angiogenesis is a novel strategy to treat patients with severe PAD with no other options by promoting the formation of collateral vessels and angiogenesis.

For patients who are not candidates for neovascularization, clinical trials of bone marrow cell transplantation in patients with CLI have revealed some degree of therapeutic effect for neovascularization [7]. To improve the survival rate of transplanted cells in ischemic tissue [8,9], we previously reported a method to promote neovascularization termed 'hypoxic preconditioning' $[10,11]$. To reduce invasiveness on collected transplanted cells, we used peripheral blood mononuclear cells (PBMNCs) instead of bone marrow cells and further examined the therapeutic effects of preconditioned PBMNCs on ischemic hindlimbs. Hypoxically pretreated PBMNCs improved microvessel density and limb blood flow in hindlimb ischemia models $[12,13]$.

Cell sheet technology has been developed to improve the engraftment of transplanted cells in grafted regions [14], and its therapeutic viability has been demonstrated in a variety of disease models [15-19]. A primary factor resulting in insufficient repair of refractory ulcers is the poor retention of grafted cells or artificial skins in wounded areas. Therefore, we considered the use of cell sheet technology to treat refractory cutaneous ulcers.

The normal healing process is regulated by a complex signaling network involving growth factors, cytokines, and chemokines and can be divided into three overlapping phases: (i) inflammatory, (ii) proliferative, and (iii) tissue remodeling phases [20]. In refractory cutaneous ulcers such as venous and diabetic leg ulcers, abnormal expression of growth factors induces chronic inflammation and delays the healing process [21, 22]. Vascular end othelial growth factor (VEGF), transforming growth factor (TGF- $\beta 1$ ), and platelet-derived growth factor BB (PDGF-BB) are necessary for the healing process from the inflammatory to the tissue repair phase (proliferative and tissue remodeling phases) $[23,24]$. It has been reported that PBMNCs provide interleukins and growth factors such as TGF- $\beta 1$ and PDGF-BB that are required for the inflammatory phase of the normal healing process [22-25]. TGF- $\beta 1$ and PDGF-BB increase the expression levels of VEGF and collagen mRNAs in fibroblasts [26]. Accordingly, we developed a mixed-cell sheet consisting of autologous fibroblasts and PBMNCs that secrete necessary growth factors from the inflammatory phase to the tissue repair phase and confirmed its efficacy for ulcer treatment in mice and rabbits [26, 27]. The mixed-cell sheet had high angiogenic potency, promoted wound closure, and led to complete natural healing. Moreover, we sought to increase the effectiveness of the sheet, and so we developed a multilayered mixed sheet.

In the present study, we examined the therapeutic efficacy of multilayered mixed-cell sheets in mice. Multilayered mixed-cell sheets have the advantage of sustained growth factor secretion. In fact, the secretion of VEGF in mixed-cell sheets was significantly greater than in single-layered mixed sheets, suggesting that multilayered mixed-cell sheets might possess enhanced angiogenic activity. The therapeutic effect of multilayered sheet delivery in the treatment of cutaneous ulcers was similar to or better than that of single-layered sheets. Taken together, multilayered mixed-cell sheets may be a potentially useful novel tool to treat cutaneous ulcers. 


\section{Cellular Physiology Cell Physiol Biochem 2018;47:201-211

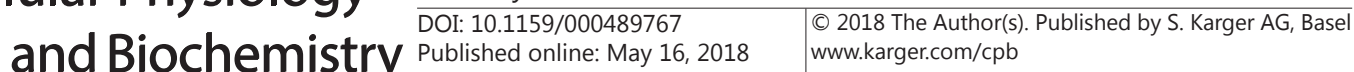 \\ Ueno et al.: Treatment of Cutaneous Ulcers with Multilayered Mixed Sheets}

\section{Materials and Methods}

\section{Animals}

Male C57BL/6 mice were purchased from Japan SLC, Inc. (Shizuoka, Japan). Male green fluorescent protein (GFP)-transgenic mice (C57BL6/Tg14) were provided by Masaru Okabe (Genome Research Centre, Osaka University, Osaka) [28]. All animal procedures were approved by the Institutional Animal Care and Use Committee of Yamaguchi University (\#31-093). The study was conducted in accordance with relevant guidelines.

\section{Isolation of PBMNCs and fibroblasts}

PBMNCs were isolated from mouse peripheral blood using Lympholyte ${ }^{\circledR}-\mathrm{M}$ (CedarLane Laboratories Ltd., Hornsby, Ontario, Canada) and cultured in CTSTM AIM V ${ }^{\circledR}$ medium (Thermo Fisher Scientific, Waltham, MA) supplemented with 10\% fetal bovine serum (FBS; Thermo Fisher Scientific). Fibroblasts were isolated from the tails of mice using collagenase (Wako, Osaka, Japan) and cultured in CTSTM AIM V ${ }^{\circledR}$ medium supplemented with $10 \%$ FBS.

\section{Preparation of cell sheets}

Single-layered mixed-cell sheets $\left(1.25 \times 10^{5}\right.$ fibroblast cells/well and $2.0 \times 10^{6}$ PBMNCs/well; singlelayered sheets) were cultured in UpCell ${ }^{\circledR} 24$-well plates (Cell Seed, Inc., Tokyo, Japan). Multilayered sheets of fibroblasts alone (5.0 × $10^{5}$ fibroblast cells/well and no PBMNCs; fibroblast sheets) and multilayered mixedcell sheets (5.0 × $10^{5}$ fibroblast cells/well and $2.0 \times 10^{6} \mathrm{PBMNCs} /$ well; multilayered sheets) were cultured in a standard 24-well culture dish. The three types of sheets were incubated under normoxic conditions $\left(37^{\circ} \mathrm{C}\right.$, atmospheric $\mathrm{O}_{2}$ concentration) for 2 days followed by hypoxic conditions $\left(33^{\circ} \mathrm{C}, 2 \% \mathrm{O}_{2}\right.$ ) for 1 day. For each culture, 2 mL CTSTM AIM V ${ }^{\circledR}$ medium and HFDM-1 (+) (Cell Science \& Technology Institute, Sendai, Japan) supplemented with 5\% FBS were used in the 24-well plates. After incubation, single-layered sheets were detached by placing them out of the incubator at room temperature. Fibroblast and multilayered sheets were detached using $10 \mathrm{PU} / \mathrm{mL}$ dispase.

\section{Enzyme-linked immunosorbent assay (ELISA)}

To assess VEGF secretion from sheets under different culture conditions, fibroblasts were seeded at different number of cells together with PBMNCs at $2.0 \times 10^{6}$ cells/well in standard 24-well plates. Cells were incubated under normoxic conditions $\left(37^{\circ} \mathrm{C}\right.$, atmospheric $\mathrm{O}_{2}$ concentration) for 2 days followed by hypoxic conditions $\left(33^{\circ} \mathrm{C}, 2 \% \mathrm{O}_{2}\right)$ for 1 day. Fibroblasts mixed with PBMNCs were seeded at $0,1.25 \times 10^{5}, 2.5 \times 10^{5}$, and $5.0 \times 10^{5}$ cells/well, because mixed-cell sheets with greater $\geq 1.0 \times 10^{6}$ fibroblast cells/well detached spontaneously during incubation. The supernatant of each well was collected, and the concentration of VEGF was measured using the mouse VEGF Quantikine immunoassay kit (R\&D Systems, Minneapolis, MN). The supernatant in the $5.0 \times 10^{5}$ fibroblast cells/well without PBMNCs was collected as control. To assess VEGF, hepatocyte growth factor (HGF), TGF- $\beta 1, \mathrm{C}-\mathrm{X}-\mathrm{C}$ motif chemokine ligand (CXCL)-1, CXCL-2, and interleukin-6 (IL-6) release from sheets cultured under different conditions, single-layered ( $1.25 \times 10^{5}$ fibroblast cells/well and $2.0 \times 10^{6} \mathrm{PBMNCs} /$ well), fibroblast (5.0 $\times 10^{5}$ fibroblast cells/well and no PBMNCs), and multilayered $\left(5.0 \times 10^{5}\right.$ fibroblast cells/well and $2.0 \times 10^{6} \mathrm{PBMNCs} /$ well $)$ sheets were cultured in 24-well plates and incubated under normoxic conditions for 2 days followed by hypoxic conditions for 1 day. For each culture, 2 mL CTSTM AIM V ${ }^{\circledR}$ medium and HFDM-1 (+) supplemented with 5\% FBS were used in the 24-well plates. After incubation, ELISA was performed as described above. Mouse Quantikine immunoassay kits were used.

Tube formation assay

Human umbilical vascular endothelial cells (HUVECs) were maintained in EGMTM-2 medium (Lonza Ltd., Basel, Switzerland) supplemented with EGMTM BulletKitTM (Lonza), trypsinized, resuspended in 10\% FBS/AIM V medium, and seeded onto Matrigel ${ }^{\circledR}$ (Corning Inc., Corning, NY)-coated 96-well plates at $2.0 \times$ $10^{4}$ cells/well $(100 \mu \mathrm{L})$. Subsequently, $100 \mu \mathrm{L}$ conditioned medium from the fresh medium, single-layered, fibroblast, and multilayered sheets were added into each well. Images of tube formation were captured after $12 \mathrm{~h}$ and measured using the Angiogenesis Analyzer for ImageJ software (National Institutes of Health, Bethesda, MD) [29, 30].

\section{KARGER}




\section{Cellular Physiology Cell Physiol Biochem 2018;47:201-211

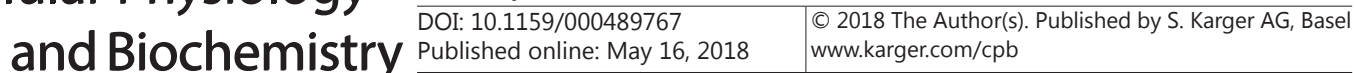 \\ Ueno et al.: Treatment of Cutaneous Ulcers with Multilayered Mixed Sheets}

\section{Migration assay}

Fibroblasts were isolated from mouse tails as above and cultured in CTSTM AIM V ${ }^{\circledR}$ Medium containing 10\% FBS. Fibroblasts were seeded into 24-well cell culture dishes at high confluence. Cells were scraped with $200 \mu \mathrm{L}$ tips to create a scratch and then further cultured for $18 \mathrm{~h}$ in conditioned medium from singlelayered, fibroblast, and multilayered sheets. Phase contrast images of the scratches were taken using a BZX710 All-in-One fluorescence microscope (Keyence Corp., Osaka, Japan) at 0 and $18 \mathrm{~h}$ after incubation. The wound area was measured using the BZ-X analyser software (Keyence).

\section{TUNEL assay}

Apoptotic cells were detected using the terminal deoxyribonucleotidyl transferase-mediated dUTPdigoxigenin nick end labelling (TUNEL) assay. Multi- and single-layered sheets were cultivated as above and transferred onto a piece of raw ham. Sheets were fixed with $10 \%$ formalin neutral buffer solution (Wako) and embedded in a paraffin block. Slides were deparaffinized, permeabilized with $0.1 \%$ Triton-X/protein blocking solution (Dako Japan, Inc., Kyoto, Japan), and then incubated with a reaction solution (In Situ Cell Death Detection Kit, Roche, Basel, Switzerland). In addition, cells were stained with 6-diamidino-2phenylindole (DAPI) to visualize the nuclei. Immunofluorescence images were acquired using a BIOREVO microscopy system (BZ-9000 Generation II system; Keyence).

\section{Cutaneous ulcer model}

Mice were injected with streptozotocin (Sigma-Aldrich Corp., St. Louis, MO). Mice with blood glucose levels of more than $300 \mathrm{mg} / \mathrm{dL}$ were used for the animal experiments as diabetes mellitus (DM) mice and anaesthetized via the inhalation of $1.5 \%$ isoflurane during the surgical procedure. For mice with ulcers on the back, full-thickness skin defects $8 \mathrm{~mm}$ in diameter were created using a surgical technique. Sheets cultured under hypoxic conditions were transplanted onto the full-thickness skin defects. The area of the skin defect was measured using ImageJ software.

Transplantation of cell sheets

Mice were divided into the following four groups according to treatment: (1) single-layered sheets ( $\mathrm{n}=10),(2)$ fibroblast sheets ( $\mathrm{n}=10),(3)$ multilayered sheets $(\mathrm{n}=9)$ ), and (4) no sheets (controls, $\mathrm{n}=9$ ). For the sheet-treated groups, the sheets were transported from plates to wounds using a tip $(1000 \mu \mathrm{L})$ with the edge cut. All ulcers were covered with Urgotul ${ }^{\circledR}$ (Laboratoires Urgo, Chenove, France), wrapped with Derma-aid ${ }^{\circledR}$ (ALCARE Co. Ltd., Tokyo, Japan), and fixed with a bandage (ALCARE). The ulcer area was measured at days 0,7 , and 14 , with the animal under anaesthesia, using Image J software.

\section{Histological analysis}

For hematoxylin and eosin (H\&E) staining, after the skin defects had healed, cutaneous tissues were resected and fixed with formalin neutral buffer solution. For fluorescent immunostaining, cutaneous tissues were resected, fixed in $10 \%$ formalin neutral buffer solution overnight at room temperature, and embedded in a paraffin block. Slides were deparaffinized, treated with antigen retrieval solution (Dako), and incubated with blocking buffer (Dako). The following antibodies were used: anti-GFP pAb (598, Medical \& Biological Laboratories, Nagoya, Aichi, Japan), anti-CD31 antibody (ab28364, Abcam, Cambridge, UK), and anti-rabbit IgG H\&L (DyLight ${ }^{\circledR}$ 550; ab96884l; Abcam).

\section{Statistical analysis}

Data were analyzed using Stata/SE 12.1 software (StataCorp, College Station, TX). Statistical significance between two groups was determined by two-tailed unpaired t-tests. Statistical significance among multiple groups was analyzed using one-way analysis of variance followed by a Bonferroni post hoc test. $\mathrm{P}<0.05$ was considered statistically significant.

\section{Results}

Preparation of multilayered mixed-cell sheets

We previously reported that mixed-cell sheets consist of autologous fibroblasts (1.25 $\times 10^{5}$ cells $)$ and PBMNCs $\left(2.0 \times 10^{6}\right.$ cells $)$ on UpCell ${ }^{\circledR} 24$-well plates [26]. To determine the maximum possible number of fibroblasts to configure mixed-cell sheets on these plates, we examined the number of fibroblasts present when the number of PBMNCs remained at $2.0 \times$ $10^{6}$ cells/well. Mixed-cell sheets detached naturally in the incubator if more than $1.25 \times 10^{5}$ 


\section{Cellular Physiology Cell Physiol Biochem 2018;47:201-211 \begin{tabular}{l|l} 
DOI: 10.1159/000489767 & and Biochemistry 2018 The Author(s). Published by S. Karger AG, Basel \\
Published online: May 16, 2018 & $\begin{array}{l}\text { www.karger.com/cpb } \\
\text { and }\end{array}$
\end{tabular}

fibroblast cells/well were seeded. Therefore, we could not peel the cell sheet off intentionally. Thus, we made multilayered mixed sheets in the standard 24-well plates. Fibroblasts were seeded in the range of $1.25 \times 10^{5}$ to $1.0 \times 10^{6}$ cells/well together with PBMNCs at $2.0 \times 10^{6}$ cells/well. Cells were incubated under normoxic conditions for 2 days followed by hypoxic conditions for 1 day. Mixed-cell sheets detached naturally in the incubator if more than or equal to $1.0 \times 10^{6}$ fibroblast cells/well were seeded. However, the multilayered sheets could not be detached with fibroblasts seeded at $1.25 \times 10^{5}$, $2.5 \times 10^{5}$, and $5.0 \times 10^{5}$ cells/well.

The concentration of VEGF in the supernatant on multilayered mixed cell sheets with $5.0 \times 10^{5}$ fibroblast cells/well was highest comparison with other experimental groups (Fig. 1A). The multilayered sheets consisting of $2.0 \times 10^{6}$ PBMNCs/well and $5.0 \times 10^{5}$ fibroblast cells/well were incubated with $10 \mathrm{PU} / \mathrm{mL}$ dispase for 40 min and peeled from the bottom of the culture dish with tweezers. The sheets had a diameter of approximately $8 \mathrm{~mm}$ and formed a round shape (Fig. 1B, left). Single-layered sheets were formed of $1.25 \times 10^{5}$ fibroblast cells and $2.0 \times 10^{6}$ PBMNCs using UpCell ${ }^{\circledR} 24$-well plates (Fig. 1B, right). The multi- and single-layered sheets were transferred to a raw ham. Macroscopic images and H\&Estained samples of multi- and single-layered sheets are shown in Figs. 1B-D. To observe whether PBMNCs existed in multilayered sheets, these sheets were constructed from PBMNCs of GFP-positive mice. Immunohistochemistry revealed GFP-positive PBMNCs in the cell sheets (Fig. 1E).

Enhanced secretion of growth factors and cytokines in multilayered sheets

To assess the paracrine effect of multilayered sheets, the concentration of VEGF, HGF, TGF- $\beta 1$, CXCL-1, CXCL-2, and IL- 6 in the supernatant was measured using an ELISA. The concentration of the growth factors and cytokines, except for IL-6, secreted from multilayered sheets was significantly higher than from single-layered and fibroblast sheets (only $5.0 \times 10^{5}$ fibroblast cells/ well; Figs. 2A-F). The concentration of IL-6 from multilayered sheets was the same as from singlelayered sheets.

\section{Angiogenic potency of multilayered sheets}

Tube formation assay was performed to investigate whether multilayered sheets enhanced angiogenic activity. HUVECs were

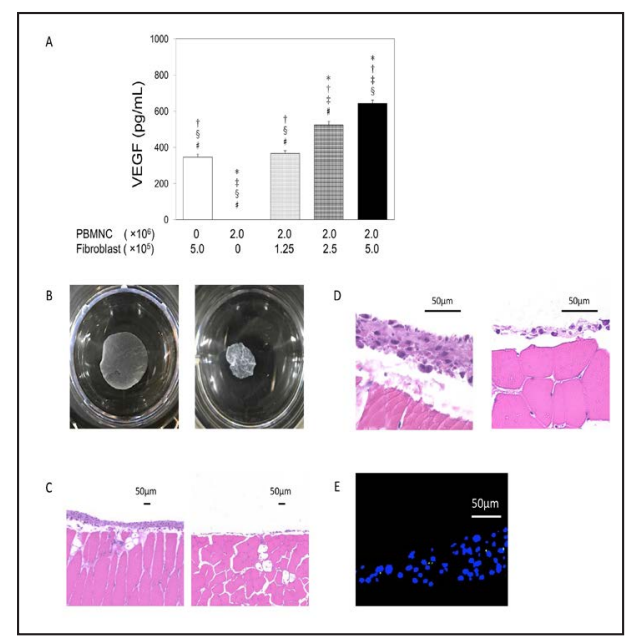

Fig. 1. Multilayered sheets consisting of fibroblasts and PBMNCs. (A) A greater number of fibroblasts in multilayered sheets resulted in increased VEGF secretion. Fibroblasts were seeded at different cell numbers together with PBMNCs at $2.0 \times 10^{6}$ cells/well in standard 24-well plates. Cells were incubated under normoxic conditions $\left(37^{\circ} \mathrm{C}\right.$, atmospheric $\mathrm{O}_{2}$ concentration) for 2 days followed by hypoxic conditions $\left(33^{\circ} \mathrm{C}, 2 \% \mathrm{O}_{2}\right)$ for 1 day. The number of fibroblasts mixed with PBMNCs were $0,1.25 \times 10^{5}, 2.5 \times 10^{5}$, and $5.0 \times 10^{5}$ cells/well. Concentration of VEGF in the supernatant were measured using ELISA. The supernatant in $5.0 \times 10^{5}$ fibroblast cells/well alone without PBMNCs was also collected as a control. ${ }^{*} \mathrm{P}<0.01$ vs. 0 PBMNCs/well and 5.0 $\times 10^{5}$ fibroblast cells/well; ${ }^{\dagger} \mathrm{P}<0.01$ vs. $2.0 \times$ $10^{6}$ PBMNCs/well and 0 fibroblast cells/well; ${ }^{\ddagger} \mathrm{P}<0.01$ vs. $2.0 \times 10^{6} \mathrm{PBMNCs} /$ well and $1.25 \times$ $10^{5}$ fibroblast cells/well; ${ }^{\S} \mathrm{P}<0.01$ vs. $2.0 \times 10^{6}$ PBMNCs/well and $2.5 \times 10^{5}$ fibroblast cells/ well; ${ }^{*} \mathrm{P}<0.01$ vs. $2.0 \times 10^{6} \mathrm{PBMNCs} /$ well and $5.0 \times 10^{5}$ fibroblast cells/well. Error bars indicate the standard error. (B) Multilayered sheets were detached from standard culture dishes incubated with $10 \mathrm{PU} / \mathrm{mL}$ dispase (left). Single-layered sheets were detached from temperature-responsive culture dishes incubated at $<20^{\circ} \mathrm{C}$ (right). (C, D) H\&E-stained images after multi- (left) and single (right)layered sheets on raw ham in low (C) and high (D) power fields. (E) PBMNCs in multilayered sheets. PBMNCs were isolated from C57BL/6 GFP-transgenic mice and the sheets were stained using anti-GFP antibody. DAPI stained the nucleus of cells constituting multilayered sheets. 


\section{Cellular Physiology Cell Physiol Biochem 2018;47:201-211 \begin{tabular}{l|l} 
DOI: 10.1159/000489767 & Ond Biochemistry 2018 The Author(s). Published by S. Karger AG, Basel \\
www.karger.com/cpb
\end{tabular} \\ Ueno et al.: Treatment of Cutaneous Ulcers with Multilayered Mixed Sheets}

Fig. 2. Synergistic effect of multilayered sheets consisting of PBMNCs and fibroblasts. (A-F) VEGF, HGF, TGF- $\beta 1$, CXCL-1, CXCL- 2 , and IL- 6 concentration in the supernatant of single-layered $\left(1.25 \times 10^{5}\right.$ fibroblast cells/well and $2.0 \times 10^{6} \mathrm{PBMNCs} /$ well), fibroblast (5.0 $\times 10^{5}$ fibroblast cells/well and no PBMNCs), and multilayered (5.0 × $10^{5}$ fibroblast cells/well and $2.0 \times 10^{6}$ PBMNCs/well) sheets, which were cultured in 24-well plates and incubated under normoxic conditions $\left(37^{\circ} \mathrm{C}\right.$, atmospheric $\mathrm{O}_{2}$ concentration) for 2 days followed by hypoxic conditions $\left(33^{\circ} \mathrm{C}, 2 \% \mathrm{O}_{2}\right)$ for 1 day. Error bars indicate standard error. Single: single-layered sheets, Fibroblast: fibroblast sheets, Multi: multilayered sheets.

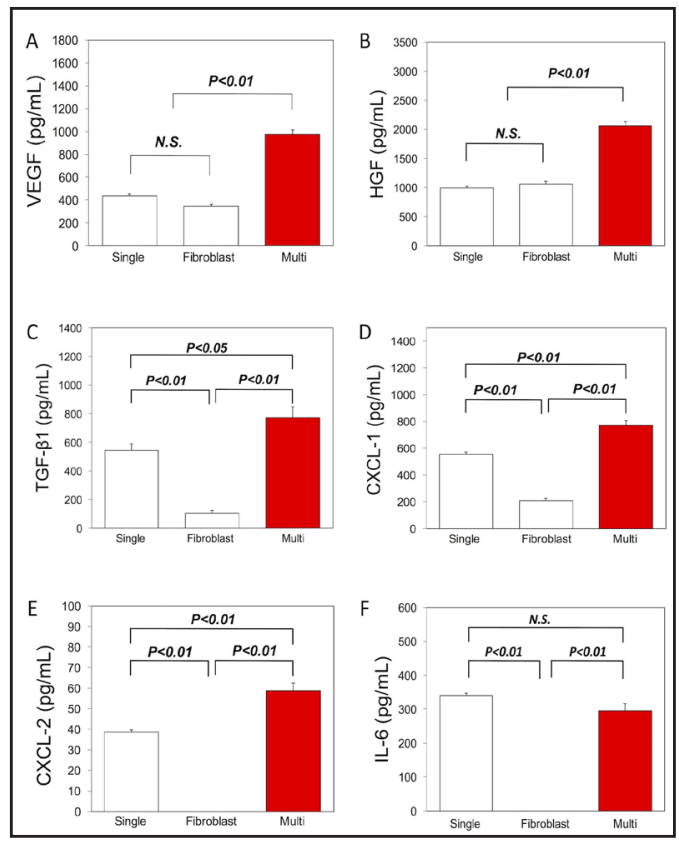

cultured with conditioned medium from single-layered, fibroblast, and multilayered sheets. Tube formation was significantly increased with conditioned medium from multilayered sheets after $12 \mathrm{~h}$ compared with fresh medium (Fig. 3A). This suggested that VEGF secreted in large amounts from multilayered sheets augmented angiogenic activity.

\section{Fibroblast migration potency of multilayered sheets}

Migration assay was performed to examine whether the multilayered sheets have potential fibroblast migration activity in a wound area. Primary mouse fibroblasts were seeded onto cell culture dishes and scratches were created in confluent cultures. The fibroblasts were then cultured with conditioned medium from sheets. Fibroblast migration was facilitated in the multilayered sheets after $18 \mathrm{~h}$ (Fig. 3B).

\section{Cell viability of multilayered mixed sheets}

TUNEL assay was performed to assess cell survival in the multilayered sheets transferred to a piece of raw ham (Fig. 3C). Although the number of fibroblasts was larger in multilayered than in single-layered sheets, the cell viability levels were the same.

\section{Therapeutic effect of multilayered sheets in a mouse cutaneous ulcer model}

To evaluate multilayered sheets as a therapeutic material for cutaneous ulcers, cell sheets derived from C57BL/6 mice were transplanted onto full-thickness skin defects on the backs of DM mice (Fig. 4A). At 7 days after initiation of therapy, the wound healing rate was significantly higher in the single- and multilayered groups than in control animals (Fig. 4B). At 14 days, although there was no significant difference in wound healing rate between the single-layered, fibroblast, and multilayered sheet groups, wound healing rates in the three groups were significantly higher than in the control group. Skin defects on the backs of DM mice were completely closed by 21 days after treatment in all four groups. However, histological analysis of the wounds revealed a clear difference in tissue regeneration between the three sheet groups and the control group. Although the anatomy of tissues from mice treated with the single- and multilayered sheets appeared normal, inflammatory-like cells were observed frequently in control tissues, indicating that abnormal tissue regeneration was induced in the control mice (Fig. 5A). CD31 staining revealed microvessel-like structures in tissues treated with multilayered sheets (Fig. 5B). Vessel lumen area in tissues treated with multilayered sheets was significantly larger than that in the control tissue. Moreover, microvessel density 


\section{Cellular Physiology Cell Physiol Biochem 2018;47:201-211 \begin{tabular}{l|l} 
DOI: 10.1159/000489767 & Ond Biochemistry 2018 The Author(s). Published by S. Karger AG, Basel \\
www.karger.com/cpb
\end{tabular}

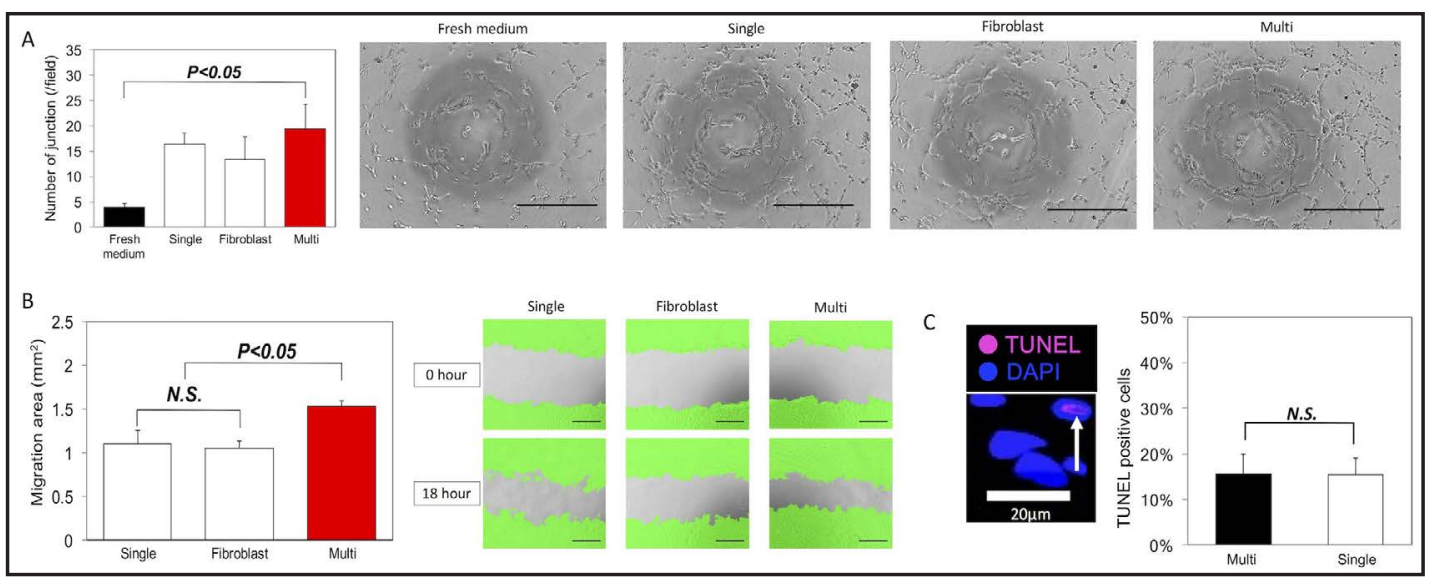

Fig. 3. Supernatant from multilayered sheets enhanced angiogenic activity and fibroblast migration. (A) Multilayered sheets enhanced angiogenic activity. HUVECs were cultured in fresh medium or conditioned medium from single-layered, fibroblast, or multilayered sheets. The conditioned media from single-layered $\left(1.25 \times 10^{5}\right.$ fibroblast cells/well and $2.0 \times 10^{6} \mathrm{PBMNCs} /$ well $)$, fibroblasts $\left(5.0 \times 10^{5}\right.$ fibroblast cells/well and no PBMNCs), and multilayered (5.0 $\times 10^{5}$ fibroblast cells/well and $2.0 \times 10^{6} \mathrm{PBMNCs} /$ well) sheets were co-cultured in 24-well culture plates and incubated under normoxic conditions $\left(37^{\circ} \mathrm{C}\right.$, atmospheric $\mathrm{O}_{2}$ concentration) for 2 days followed by hypoxic conditions $\left(33^{\circ} \mathrm{C}, 2 \% \mathrm{O}_{2}\right)$ for 1 day. The number of junctions in the field was counted at $\times 10$ microscopic magnification; scale bar indicates $500 \mu \mathrm{m}$. (B) Cell proliferative activity of multilayered sheets was analyzed using migration assay. Confluent mouse fibroblasts were scraped to create a scratch approximately $1.0 \mathrm{~mm}$ in size and cells were cultivated further in conditioned medium for $18 \mathrm{~h}$. Conditioned media of single-layered (1.25 $\times 10^{5}$ fibroblast cells/well and $2.0 \times 10^{6} \mathrm{PBMNCs} /$ well), fibroblast (5.0 $\times 10^{5}$ fibroblast cells/well and no PBMNCs), and multilayered (5.0 $\times 10^{5}$ fibroblast cells/well and $2.0 \times 10^{6} \mathrm{PBMNCs} /$ well) sheets were cultured in 24-well plates and incubated under normoxic conditions $\left(37^{\circ} \mathrm{C}\right.$, atmospheric $\mathrm{O}_{2}$ concentration) for 2 days followed by hypoxic conditions $\left(33^{\circ} \mathrm{C}, 2 \% \mathrm{O}_{2}\right)$ for 1 day. Wound closure area was measured and compared among the experimental groups. Cells were colored in green virtually to visualize the wound closure area; scale bar indicates $500 \mu \mathrm{m}$. (C) Apoptotic assay in multilayered and single-layered sheets. Arrowhead indicates TUNEL-positive cell. Error bars indicate standard error. Single: single-layered sheets, Fibroblast: fibroblast sheets, Multi: multilayered sheets.

in tissues treated with multilayered sheets was significantly higher than in the other tissues (Fig. 5C).

\section{Discussion}

We have described the development of mouse multilayered mixed-cell sheets consisting of autologous fibroblasts and PBMNCs, and their curative effect on ulcer healing in mice. Ulcer healing requires a wellorchestrated interplay of

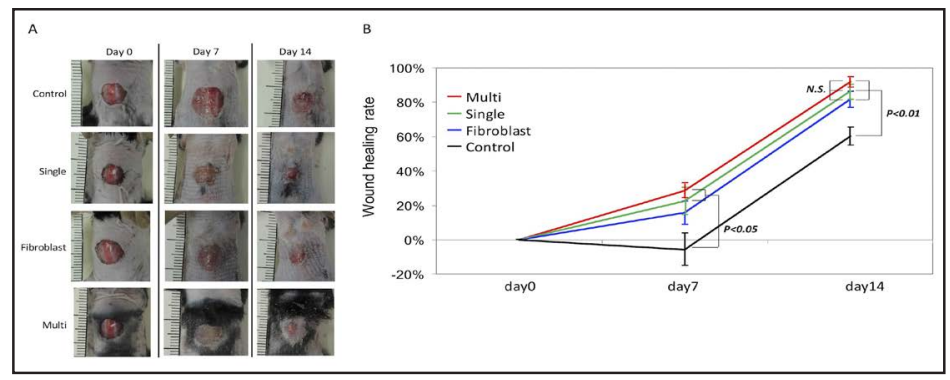

Fig. 4. Therapeutic effect of multilayered sheets. (A) Wound healing after single-layered, fibroblast, and multilayered sheet transplantation onto full-thickness skin defects on the backs of DM mice at days 1, 7, and 14. Control shows DM mice that did not receive the experimental treatment. (B) Wound healing rate at different time points after treatment. Wound area was measured with Image J software. Error bars indicate standard error. Single: single-layered sheets, Fibroblast: fibroblast sheets, Multi: multilayered sheets. cell-matrix and cell-cell signalling. Fibroblasts have an important role in facilitating the interaction of extracellular matrix (ECM) with keratinocytes and endothelial cells for ulcer healing [31]. In addi- 
tion, these three cell types secrete vascularizationassociated growth factors, including VEGF, TGF- $\beta 1$, and HGF [32]. Fibroblasts can be isolated and cultured from various tissues, and PBMNCs are harvested easily from patients in the clinic and can be transplanted to ischemic tissues for angiogenesis treatment [33-35]. It is known that not only growth factors but also inflammatory cytokines and chemokines, such as IL-6 and CXCL, are essential for the normal wound-healing process $[20,36]$. This multilayered mixed-cell sheet secrets these growth factors, inflammatory cytokines, and chemokines, which have the potential to augment the normal woundhealing process.

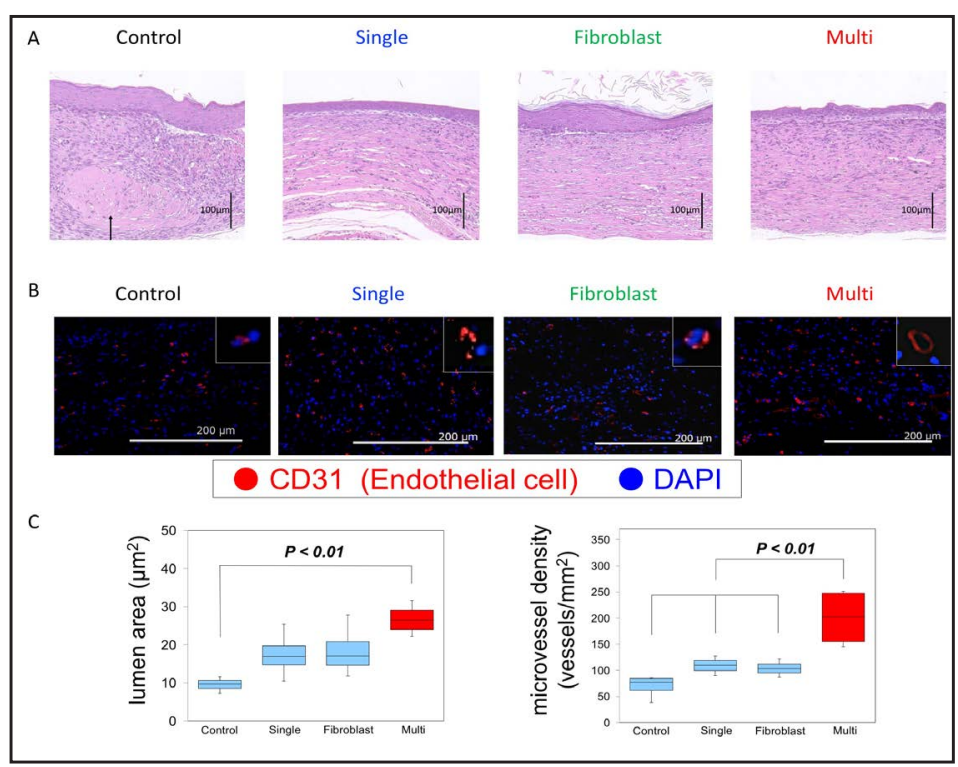

Fig. 5. Angiogenesis in multilayered sheets. (A) H\&E- and (B) CD31stained images 21 days after single-layered, fibroblast, and multilayered sheet transplantation. CD31 is a marker of endothelial cells. (C) Comparison of vessel lumen area and microvessel density in tissues treated with multilayered sheets. Magnification $\times 40$. Error bars indicate the standard error. Single: single-layered sheets, Fibroblast: fibroblast sheets, Multi: multilayered sheets.

Cell sheet technology is

a recent development. Instead of detaching cells with the conventional dispase or trypsin, a novel temperature-responsive culture dish enables detachment as a single continuous sheet of cells while maintaining the ECM [37]. Using this technology, fibroblasts, as adherent cells, formed layers on our mixed-cell sheets and these cell sheets with ECM were transplanted to ulcers. However, it is very difficult to form multilayered sheets with a temperature-responsive culture dish by using this method. Therefore, we attempted to make multilayered sheets on a typical culture dish and detach them using a small amount of dispase. With this method, the multilayered sheets incorporated a subset of PBMMCs as in our previous study [26], and the population of PBMNCs was considered to contribute to angiogenesis [38].

In addition, we developed a novel and feasible protocol called 'hypoxic preconditioning' to enhance the cellular functions of transplanted cells using hemeoxygenase- 1 and hexokinase-2 [39], and improve the retention of transplanted cells through CXCR4 and integrin $\alpha \mathrm{M}$ in mice $[40,41]$. In our previous study in rabbits, hypoxic preconditioned PBMNCs enhanced cell adhesive ability and angiogenesis, and transplantation of the hypoxic preconditioned PBMNCs into muscle improved blood flow at the ischemic hindlimb [13]. Hypoxic preconditioning has also been reported to increase secretion of VEGF in singlelayered sheets $[26,27]$. Therefore, hypoxic preconditioning may be effective for promoting secretion of growth factors in multilayered sheets.

To assess the effect of ulcer healing in vivo, we used mice with streptozotocin-induced DM to slow wound healing. Three multilayered sheet-treated groups had a significantly higher rate of ulcer wound healing on day 14 compared with the control group. In particular, single-layered and multilayered sheet-treated groups also had significantly enhanced wound healing on day 7 compared with the control group. The facilitated wound healing in the two types of mixed sheet-treated groups reflected an increase in growth factors and cytokines. This finding might indicate that the three types of cell sheets secrete sufficient amounts of several growth factors, including VEGF, to promote wound healing. Conversely, there were no differences among the three sheet-treated groups on days 7 and 14. However, 


\section{Cellular Physiology Cell Physiol Biochem 2018;47:201-211 $\begin{array}{lll}\text { DOI: 10.1159/000489767 } & \text { and Biochemistry } & \begin{array}{l}\text { O } 2018 \text { The Author(s). Published by S. Karger AG, Basel } \\ \text { wwww.karger.com/cpb }\end{array}\end{array}$ \\ Ueno et al.: Treatment of Cutaneous Ulcers with Multilayered Mixed Sheets}

we observed a significant increase in mature microvascular angiogenesis in the skin treated with multilayered sheets as these sheets produce more growth factors, including VEGF, than single-layered sheets. There are no appropriate animal models that reflect human refractory cutaneous ulcers. Therefore, a skin defect model was used in this study. Hence, the efficacy of multilayered mixed sheets may not have been fully demonstrated. Based on these results, it is expected that multilayered sheets will provide effective treatment for refractory cutaneous ulcers in clinical trials.

In the present study, our data clearly showed that multilayered sheets had a curative effect on skin defect models for ulcer treatment. These sheets promoted wound healing and microvascular angiogenesis in the skin by supplying growth factors and cytokines. Our findings suggest that multilayered sheets may be a useful tool for treatment of refractory ulcers.

\section{Acknowledgements}

We thank Yukari Hironaka and Kazuko Tanaka for their technical assistance. This work was supported by a JSPS Grant-in-Aid for Scientific Research B (15H04939 to K.H.), a JSPS Grant-in-Aid for Scientific Research C (16K10661 to R.S.), the R\&D Promotion Subsidy System (Yamaguchi Prefecture Government) (to K.H.), and the Uehara Memorial Foundation (to K.U.).

\section{Disclosure Statement}

No conflict of interests exists.

\section{References}

1 Vuorisalo S, Venermo M, Lepäntalo M: Treatment of diabetic foot ulcers. J Cardiovasc Surg 2009;50:275291.

2 Singh N, Armstrong DG, Lipsky BA: Preventing foot ulcers in patients with diabetes. JAMA 2005;293:217228.

-3 Wu SC, Driver VR, Wrobel JS, Armstrong DG: Foot ulcers in the diabetic patient, prevention and treatment. Vasc Health Risk Manag 2007;3:65-76.

-4 Aschermann I, Noor S, Venturelli S, Sinnberg T, Mnich CD, Busch C: Extracorporal Shock Waves Activate Migration, Proliferation and Inflammatory Pathways in Fibroblasts and Keratinocytes, and Improve Wound Healing in an Open-Label, Single-Arm Study in Patients with Therapy-Refractory Chronic Leg Ulcers. Cell Physiol Biochem 2017;41:890-906.

5 Vartanian SM, Conte MS: Surgical intervention for peripheral arterial disease. Circ Res 2015;116:16141628.

6 Brass EP, Anthony R, Dormandy J, Hiatt WR, Jiao J, Nakanishi A, McNamara T, Nehler M, Circulase I: Parenteral therapy with lipo-ecraprost, a lipid-based formulation of a PGE1 analog, does not alter sixmonth outcomes in patients with critical leg ischemia. J Vasc Surg 2006;43:752-759.

7 Franz RW, Parks A, Shah KJ, Hankins T, Hartman JF, Wright ML: Use of autologous bone marrow mononuclear cell implantation therapy as a limb salvage procedure in patients with severe peripheral arterial disease. J Vasc Surg 2009;50:1378-1390.

8 Cramer T, Yamanishi Y, Clausen BE, Förster I, Pawlinski R, Mackman N, Haase VH, Jaenisch R, Corr M, Nizet V, Firestein GS, Gerber HP, Ferrara N, Johnson RS: HIF-1alpha is essential for myeloid cell-mediated inflammation. Cell 2003:112:645-657.

-9 Nian M, Lee P, Khaper N, Liu P: Inflammatory cytokines and postmyocardial infarction remodeling. Circ Res 2004;94:1543-1553. 


\section{Cellular Physiology Cell Physiol Biochem 2018;47:201-211 \begin{tabular}{l|l} 
DOI: 10.1159/000489767 & Ond Biochemistry \\
Published online: May 16, 2018 & $\begin{array}{l}\text { 2018 The Author(s). Published by S. Karger AG, Basel } \\
\text { www.karger.com/cpb }\end{array}$
\end{tabular} \\ Ueno et al.: Treatment of Cutaneous Ulcers with Multilayered Mixed Sheets}

10 Li TS, Hamano K, Suzuki K, Ito H, Zempo N, Matsuzaki M: Improved angiogenic potency by implantation of ex vivo hypoxia prestimulated bone marrow cells in rats. Am J Physiol Heart Circ Physiol 2002;283:468473.

11 Kubo M, Li TS, Kurazumi H, Takemoto Y, Ohshima M, Murata T, Katsura S, Morikage N, Furutani A, Hamano K: Hypoxic preconditioning enhances angiogenic potential of bone marrow cells with aging-related functional impairment. Circ J 2012;76:986-994.

12 Kubo M, Li TS, Suzuki R, Shirasawa B, Morikage N, Ohshima M, Qin SL, Hamano K: Hypoxic preconditioning increases survival and angiogenic potency of peripheral blood mononuclear cells via oxidative stress resistance. Am J Physiol Heart Circ Physiol 2008;294:H590-595.

-13 Kudo T, Hosoyama T, Samura M, Katsura S, Nishimoto A, Kugimiya N, Fujii Y, Li T-S, Hamano K: Hypoxic preconditioning reinforces cellular functions of autologous peripheral blood-derived cells in rabbit hindlimb ischemia model. Biochemical and Biophysical Research Communications 2014;444:370-375.

14 Matsuura K, Utoh R, Nagase K, Okano T: Cell sheet approach for tissue engineering and regenerative medicine. J Control Release 2014;190:228-239.

15 Sawa Y, Miyagawa S: Cell sheet technology for heart failure. Curr Pharm Biotechnol 2013;14:61-66.

16 Ohki T, Yamato M, Ota M, Takagi R, Murakami D, Kondo M, Sasaki R, Namiki H, Okano T, Yamamoto M: Prevention of esophageal stricture after endoscopic submucosal dissection using tissue-engineered cell sheets. Gastroenterology 2012;143:582-588 e582.

-17 Watanabe K, Yamato M, Hayashida Y, Yang J, Kikuchi A, Okano T, Tano Y, Nishida K: Development of transplantable genetically modified corneal epithelial cell sheets for gene therapy. Biomaterials 2007;28:745-749.

18 Akizuki T, Oda S, Komaki M, Tsuchioka H, Kawakatsu N, Kikuchi A, Yamato M, Okano T, Ishikawa I: Application of periodontal ligament cell sheet for periodontal regeneration: a pilot study in beagle dogs. J Periodontal Res 2005;40:245-251.

19 Takeuchi Y, Ueno K, Mizoguchi T, Samura M, Harada T, Oga A, Murata T, Hosoyama T, Morikage N, Hamano K: Development of Novel Mouse Model of Ulcers Induced by Implantation of Magnets. Sci Rep 2017;7:4843.

20 Behm B, Babilas P, Landthaler M, Schreml S: Cytokines, chemokines and growth factors in wound healing. I Eur Acad Dermatol Venereol 2012;26:812-820.

21 Demidova-Rice TN, Hamblin MR, Herman IM: Acute and impaired wound healing: pathophysiology and current methods for drug delivery, part 1: normal and chronic wounds: biology, causes, and approaches to care. Adv Skin Wound Care 2012;25:304-314.

22 Vellayappan MV, Jaganathan SK, Manikandan A: Nanomaterials as a game changer in the management and treatment of diabetic foot ulcers. RSC Adv 2016;6:114859-114878.

23 Eming SA, Krieg T, Davidson JM: Inflammation in wound repair: molecular and cellular mechanisms. J Invest Dermatol 2007;127:514-525.

24 Röhl J, Zaharia A, Rudolph M, Murray RZ: The role of inflammation in cutaneous repair. Wound Practice and Research 2015;23:8-15.

-25 Samura M, Morikage N, Suehiro K, Tanaka Y, Nakamura T, Nishimoto A, Ueno K, Hosoyama T, Hamano K: Combinatorial Treatment with Apelin-13 Enhances the Therapeutic Efficacy of a Preconditioned Cell-Based Therapy for Peripheral Ischemia. Sci Rep 2016;6:19379.

-26 Ueno K, Takeuchi Y, Samura M, Tanaka Y, Nakamura T, Nishimoto A, Murata T, Hosoyama T, Hamano K: Treatment of refractory cutaneous ulcers with mixed sheets consisting of peripheral blood mononuclear cells and fibroblasts. Sci Rep 2016;6:28538.

27. Takeuchi Y, Ueno K, Mizoguchi T, Samura M, Harada T, Oga A, Murata T, Hosoyama T, Morikage N, Hamano K: Ulcer healing effect of autologous mixed sheets consisting of fibroblasts and peripheral blood mononuclear cells in rabbit ischemic hind limb. Am J Transl Res 2017;9:2340-2351.

28 Okabe M, Ikawa M, Kominami K, Nakanishi T, Nishimune Y: 'Green mice' as a source of ubiquitous green cells. FEBS Letters 1997;407:313-319.

29 Arnaoutova I, George J, Kleinman HK, Benton G: The endothelial cell tube formation assay on basement membrane turns 20: state of the science and the art. Angiogenesis 2009;12:267-274.

-30 Tanaka Y, Shirasawa B, Takeuchi Y, Kawamura D, Nakamura T, Samura M, Nishimoto A, Ueno K, Morikage N, Hosoyama T, Hamano K: Autologous preconditioned mesenchymal stem cell sheets improve left ventricular function in a rabbit old myocardial infarction model. Am J Transl Res 2016;8:2222-2233. 


\section{Cellular Physiology Cell Physiol Biochem 2018;47:201-211 \begin{tabular}{l|l} 
DOI: 10.1159/000489767 & Ond Biochemistry 2018 The Author(s). Published by S. Karger AG, Basel \\
www.karger.com/cpb
\end{tabular}}

Ueno et al.: Treatment of Cutaneous Ulcers with Multilayered Mixed Sheets

31 Cerqueira MT, Pirraco RP, Martins AR, Santos TC, Reis RL, Marques AP: Cell sheet technology-driven reepithelialization and neovascularization of skin wounds. Acta Biomater 2014;10:3145-3155.

-32 Liu Y, Luo H, Wang X, Takemura A, Fang YR, Jin Y, Suwa F: In vitro construction of scaffold-free bilayered tissue-engineered skin containing capillary networks. Biomed Res Int 2013;2013:561410.

33 Horie T, Onodera R, Akamatsu M, Ichikawa Y, Hoshino J, Kaneko E, Iwashita C, Ishida A, Tsukamoto T, Teramukai S, Fukushima M, Kawamura A: Long-term clinical outcomes for patients with lower limb ischemia implanted with G-CSF- mobilized autologous peripheral blood mononuclear cells. Atherosclerosis 2010;208:461- 466.

-34 Moriya J, Minamino T, Tateno K, Shimizu N, Kuwabara Y, Sato Y, Saito Y, Komuro I: Long-term outcome of therapeutic neovascularization using peripheral blood mononuclear cells for limb ischemia. Circ Cardiovasc Interv 2009;2:245-254.

35 Tateishi-Yuyama E, Matsubara H, Murohara T, Ikeda U, Shintani S, Masaki H, Amano K, Kishimoto Y, Yoshimoto K, Akashi H, Shimada K, Iwasaka T, Imaizumi T: Therapeutic angiogenesis for patients with limb ischemia by autologous transplantation of bone-marrow cells: a pilot study and a randomized controlled trial. Lancet 2002;360:427-435.

36 Zaja-Milatovic S, Richmond A: CXC chemokines and their receptors: A case for a significant biological role in cutaneous healing. Histol Histopathol 2008;23:1399-1407.

37 Murakami D, Yamato M, Nishida K, Ohki T, Takagi R, Yang J, Namiki H, Okano T: The effect of micropores in the surface of temperature- responsive culture inserts on the fabrication of transplantable canine oral mucosal epithelial cell sheets. Biomaterials 2006;27:5518-5523.

-38 Chauhan SK, Lee HK, Lee HS, Park EY, Jeong E, Dana R: PTK7+ Mononuclear Cells Express VEGFR2 and Contribute to Vascular Stabilization by Upregulating Angiopoietin-1. Arterioscler Thromb Vasc Biol 2015;35:1606-1615.

39. Kubo M, Li TS, Suzuki R, Ohshima M, Qin SL, Hamano K: Short-term pretreatment with low-dose hydrogen peroxide enhances the efficacy of bone marrow cells for therapeutic angiogenesis. Am J Physiol Heart Circ Physiol 2007;292:H2582-2588.

40 Liu H, Xue W, Ge G, Luo X, Li Y, Xiang H, Ding X, Tian P, Tian X: Hypoxic preconditioning advances CXCR4 and CXCR7 expression by activating HIF-1alpha in MSCs. Biochem Biophys Res Commun 2010;401:509-515.

41 Kubo M, Li TS, Kamota T, Ohshima M, Qin SL, Hamano K: Increased expression of CXCR4 and integrin alphaM in hypoxia-preconditioned cells contributes to improved cell retention and angiogenic potency. J Cell Physio 2009;220:508-514. 